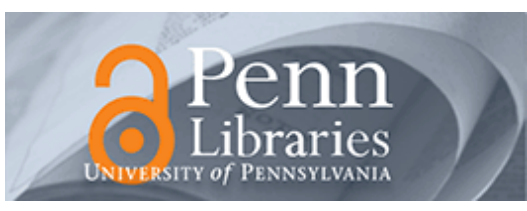

University of Pennsylvania
ScholarlyCommons

Departmental Papers (Classical Studies)

Classical Studies at Penn

1986

\title{
Acontius, Milanion, and Gallus: Vergil, Ecl. $10.52-61$
}

Joseph Farrell

University of Pennsylvania, jfarrell@sas.upenn.edu

Ralph M. Rosen

University of Pennsylvania, rrosen@sas.upenn.edu

Follow this and additional works at: http://repository.upenn.edu/classics_papers

Part of the Classics Commons

\section{Recommended Citation}

Farrell, J., \& Rosen, R. M. (1986). Acontius, Milanion, and Gallus: Vergil, Ecl. 10.52-61. Transactions of the American Philological Association, 116 241-254. http://dx.doi.org/10.2307/283919 


\title{
Acontius, Milanion, and Gallus: Vergil, Ecl. 10.52-61
}

\begin{abstract}
In the rambling sequence of thoughts in Ecl. 10.31-69 that expresses the troubled state of the lovesick Gallus, Vergil depicts his friend as proposing to abandon elegy for bucolic poetry, and to take up a pair of activities presumably related to this change. These activities--carving love-messages on trees and hunting--are to some extent typical of the unrequited literary, especially pastoral, lover. But these projects may have more than just a general amatory import. It has long been held that both motifs had previously appeared in Gallus' own love poetry. More recently, D. 0. Ross has refined this theory, arguing that Gallus in his Amores had not merely used these general motifs, but had in fact adduced specific stories in which they appear as exempla to characterize his own amatory/literary situation. According to Ross, Vergil is alluding here to two passages in which Gallus had identified himself with two famous lovers of literary myth, namely Acontius and Milanion. While this theory has found adherents, it has also incurred significant resistance. This paper has two purposes: first, to support Ross's argument that Gallus used Acontius and Milanion as erotic exempla in the Amores; second, to argue that specific sources for both Gallan exempla can be identified in the poetry of Callimachus. On this basis, we infer that the Gallan allusions in Ecl. 10 are intended not only to honor Gallus, but in the process of honoring him to call attention to his Callimachean doctrina.
\end{abstract}

\section{Disciplines}

Arts and Humanities | Classics 
Transactions of the American Philological Association 116 (1986) 241-254

\title{
ACONTIUS, MILANION, AND GALLUS: VERGIL, ECL. 10.52-61
}

\author{
RALPH M. ROSEN \\ AND \\ JOSEPH FARRELL \\ University of Pennsylvania
}

In the rambling sequence of thoughts in Ecl. 10.31-69 that expresses the troubled state of the lovesick Gallus, Vergil depicts his friend as proposing to abandon elegy for bucolic poetry, and to take up a pair of activities presumably related to this change. These activities-carving love-messages on trees and hunting-are to some extent typical of the unrequited literary, especially pastoral, lover: ${ }^{1}$

certum est in silvis inter spelaea ferarum malle pati tenerisque meos incidere amores arboribus: crescent illae, crescetis, amores. interea mixtis lustrabo Maenala Nymphis aut acris venabor apros. non me ulla vetabunt frigora Parthenios canibus circumdare saltus. iam mihi per rupes videor lucosque sonantis ire, libet Partho torquere Cydonia cornu spicula-tamquam haec sit nostri medicina furoris, aut deus ille malis hominum mitescere discat. (10.52-61)

But these projects may have more than just a general amatory import. It has long been held that both motifs had previously appeared in Gallus' own love poetry. ${ }^{2}$ More recently, D. O. Ross has refined this theory, arguing that Gallus in his Amores had not merely used these general motifs, but had in fact adduced specific stories in which they appear as exempla to characterize his own amatory/literary situa-

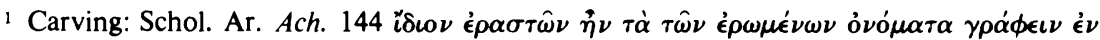

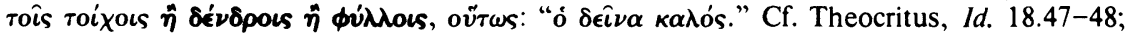
Glaucus, AP 9.341.3-4; Ecl. 5.13-15; Ovid Her. 5.21-28. For hunting the locus classicus is Phaedra's speech at Euripides, Hipp. 215-31.

2 Servius on Ecl. 10.46 comments hi autem omnes versus Galli sunt, de ipsius translati carminibus. F. Skutsch, Aus Vergils Frühzeit (Leipzig 1901) and Gallus und Vergil (Leipzig 1906) attempted to read both Ecl. 6 and 10 as catalogues of Gallus' works. In particular Skutsch argues that Ecl. 10.55-60 referred to a Gallan "Jagdelegie" (Frühzeit 20). 
tion. ${ }^{3}$ According to Ross, Vergil is alluding here to two passages in which Gallus had identified himself with two famous lovers of literary myth, namely Acontius and Milanion. ${ }^{4}$ While this theory has found adherents, it has also incurred significant resistance. ${ }^{5}$ This paper has two purposes: first, to support Ross's argument that Gallus used Acontius and Milanion as erotic exempla in the Amores; ${ }^{6}$ second, to argue that specific sources for both Gallan exempla can be identified in the poetry of Callimachus. On this basis, we infer that the Gallan allusions in Ecl. 10 are intended not only to honor Gallus, but in the process of honoring him to call attention to his Callimachean doctrina.

To suggest that Vergil wished to honor Gallus as a poet in the tradition of Callimachus will surprise no one. This motive is one of the chief reasons for Gallus' appearance in Ecl. 6. It is true of course that in Ecl. 10, the character Gallus refers to his previous work as Chalcidico quae sunt mihi condita versu / carmina (50-51)-a clear reference to Euphorion of Chalcis as the model of his Amores-and declares his intention to tune this work to the pastoris Siculi ... avena (52), i.e. to write bucolic poetry on the model of Theocritus. ${ }^{7}$ Some may therefore object that $E c l$. 10 explicitly characterizes Gallus as something other than a Callimachean. To meet this objection, we may turn again to Ecl. 6, which requires us to assume that Gallus' and Vergil's poetry was modeled on that of many diverse predecessors simultaneously. Specifically, one finds that Vergil's bucolic Muse accommodates with ease Callimachus, Apollonius of Rhodes, Hesiod, and even Homer-not to mention a succession of Roman poets culminating in Gallus himself. ${ }^{8}$ Indeed, Gallus' privileged position in this list seems to

3 D. O. Ross, Backgrounds to Augustan Poetry: Gallus, Elegy, and Rome (Cambridge 1975) 87-91 (cited hereafter as "Ross"). On Milanion and Acontius in Gallus' poetry see Ross 61-65 and 72-74 respectively. Essentially, Ross argues that similarities of diction and situation among Ecl. 10.52-61, Propertius 1.1.9-16 and 18.19-22, and Ovid AA 2.185-96 indicate a common source and point specifically to Gallus' Amores. See below, pp. 246-48.

4 Ross 89-91.

${ }^{5}$ For example, while E. A. Schmidt (Gnomon 51 [1979] 435) finds this theory "interessant und diskussionswürdig," D. West (Latomus 37 [1978] 210) labels it "not sound." See also the reservations expressed by J. E. G. Zetzel, "Gallus, Elegy, and Ross," $C P 72$ (1977) 253-54.

${ }^{6}$ Our use of the term "exempla" perhaps begs certain questions, but is convenient. Strictly speaking, however, we are not concerned in this paper with Ross's theories on the "subjective" or "objective" character of Gallan elegy, on Gallus' development as an elegist, or about his general influence on the course of Latin literature. We address ourselves only to the questions of whether the stories of Acontius and Milanion actually appeared in the Amores, and of Gallus' sources for these stories.

7 Skutsch (Frühzeit [äbove, note 2] 25) argues that there was a pastoral element in the Amores; cf. Ross 86.

8 The basic discussion of the various poets, genres, and styles catalogued in this poem remains Z. Stewart, "The Song of Silenus," HSCP 64 (1959) 179-205; cf. J. P. Elder, 
indicate that his work somehow embraces all those poetic traditions mentioned or alluded to in the eclogue; and his initiation scene (64-73) makes it clear that these traditions are not incompatible with Callimachean literary principles. ${ }^{9}$ What Vergil seems to suggest here is Callimachus' unique importance in showing the proper way to emulate other poets. It is therefore possible-and for poets such as Vergil and Gallus even necessary - to be both an aemulus cuiusvis and an imitator Callimachi. ${ }^{10}$

Ecl. 10, however, offers evidence that Gallus used Callimachean material as well as Callimachean technique. If, as Ross believes, the Amores did in fact tell of Acontius' love for Cydippe, then Callimachus presents himself as Gallus' likeliest source. ${ }^{11}$ The story is related at length and in prominent position in the third book of the Aetia, which despite its fragmentary state is our earliest and chief extant poetic account. The story does not appear in the 'Е $\rho \omega ́ \tau \iota \kappa \alpha ~ \Pi \alpha \theta \dot{\eta} \mu \alpha \tau \alpha$ of Gallus' mentor Parthenius of Nicaea; nor is it explicitly attested in any other Hellenistic or Roman author before Ovid. ${ }^{12}$ On the other hand, there is nothing to indicate that Callimachus ever related the story of Milanion and Atalanta. But a passage in Callimachus' third hymn (In Dianam) exhibits great similarities of diction to Ecl. 10.55-61, Vergil's putative allusion to Gallus' Milanion exemplum. We shall argue that the similarities between Ecl. 10.55-61 and In Dianam 81-89 are too numerous and detailed to be coincidental. Furthermore, these parallels make better sense if Gallus had already used the same Cal-

\footnotetext{
"Non iniussa cano: Virgil's Sixth Eclogue," HSCP 65 (1961) 109-25. On the matter of Callimachus and Vergil's "poetic genealogy," see the following note.

9 R. Pfeiffer, "Ein neues Altersgedicht des Kallimachos," Hermes 63 (1928) 321-23; cf. O. Skutsch, "Zu Vergils Eklogen," RhM 99 (1956) 193-95; W. Wimmel, Kallimachos in Rom: die Nachfolge seines apologetischen Werkes in der Augusteerzeit, Hermes Einzelschriften 16 (Wiesbaden 1960) 132-47; W. Clausen, "Callimachus and Latin Poetry," GRBS 5 (1964) 181-96, esp. 193-95; Ross 18-38.

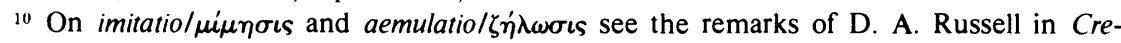
ative Imitation and Latin Literature, ed. D. West and T. Woodman (Cambridge 1979) 9-11; cf. G. Williams, "Roman Poets as Literary Critics: Some Aspects of imitatio," ICS 8 (1983) 211-37, with further references.

11 Virtually all critics have identified Callimachus as the source of Propertius 1.18.21-22, where the motif of carving love messages on trees appears, as in $E c l$. 10, without explicit reference to Acontius: see especially F. Jacoby, "Zur Entstehung der römischen Elegie," RhM 60 (1905) 58-59; A. La Penna, Properzio (Firenze 1951) 167; F. Cairns, "Propertius i.18 and Callimachus, Acontius and Cydippe," CR 19 (1969) 131-34; P. Fedeli, Sesto Properzio: Il primo libro delle elegie (Firenze 1980) 434. Ross (71-74 and 88-89) argues convincingly from parallels between Propertius 1.18 and Ecl. 10 that both poems refer to Gallus' telling of the Acontius story in the Amores and that Callimachus was Gallus' source (and, therefore, ultimately Propertius' and Vergil's as well).

${ }_{12}$ Callimachus (fr. 75.53-55 Pf.) cites the fifth-century(?) local historian Xenomedes of Ceos $(F G r H 442)$ as his source for the story.
} 
limachean passage as the basis for a Milanion exemplum. Finally, it seems likely that the particular way in which Vergil uses his Gallan/Callimachean material in these lines is designed to accommodate the Acontius reference that Ross detects in the preceding lines ( $E c l$. 10.52-54).

To illustrate these points, let us first consider the epithets that Vergil uses in lines 55-61: Maenala, Parthenios, Partho, Cydonia. The first two of these point clearly to the Arcadian venue of Gallus' proposed expedition. In view of this fact, one may wonder why Gallus is to hunt with equipment imported from completely different parts of the world. Parthian and Cretan archers, of course, were proverbially skilled in antiquity, and the appearance in any context of these bows and arrows need only imply high-quality equipment. ${ }^{13}$ Cydonius, however, was not the only word available to designate Cretan hunting equipment, and it seems likely that Vergil chose it with literary precedents in mind. ${ }^{14}$ The adjective occurs here for the first time in extant Latin

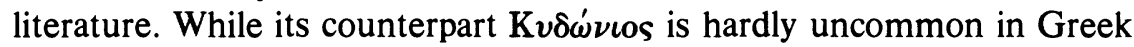
literature, ${ }^{15}$ its occurrence in Callimachus' In Dianam seems especially relevant to the Vergilian passage:

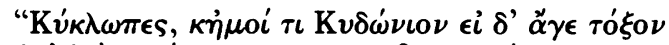

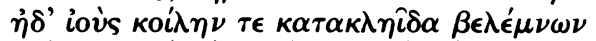

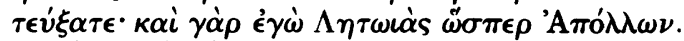

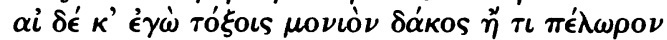

${ }_{13}$ Both R. Coleman, Vergil: Eclogues (Cambridge 1977) 291 and R. D. Williams, Virgil: The Eclogues and Georgics (New York 1979) 132 refer (ad 10.59) to the renown of Parthian and Cretan archers and to the correspondingly high quality of their gear. Callimachus speaks of Cydonian gear in particular as the best (fr. 560 Pf.), and Artemis demands such equipment of the Cyclopes, insisting that she is entitled to the same treatment as Apollo (In Dianam 81-83; see below pp. 245-46 and note 16). Parthian archers, too, were legendary for their skill; but by regarding Vergil's decision to speak here of combined Parthian and Cydonian gear in particular as a mere cliché, commentators seem to us to underestimate the care with which he composed.

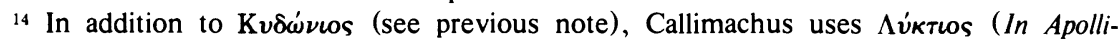
nem 33, of the god's bow), after the Cretan village of Lyktos: cf. Ep. 37.1; AP 6.75.7 (Paulus Silentiarius) and 326.1 (Leonidas of Alexandria). Vergil himself speaks of a Cressam pharetram at Geo. 3.345, and of Cnosia and Gortynia spicula at Aen. 5.306 and 11.773 respectively. The last passage (spicula torquebat Lycio Gortynia cornu) in form virtually duplicates Ecl. 10.59-60 (libet Partho torquere Cydonia cornu / spicula), as does [Vergil] Ciris 299 (Cnosia nec Partho contendens spicula cornu; cf. Cretaea sagitta 115). Horace mentions calami spicula Cnosii (Carm. 1.15.17) as well as a Cydonio arcu (Carm. 4.9.17-18: see p. 252, note 50 below). Ovid has Gortyniaco arcu (Met. 7.778), Lucan Gortynis harundo (6.214). It is perhaps worth mentioning that none of these alternative Cretan ethnica is metrically interchangeable with Cydonius.

${ }_{15}$ Most of the citations in Pape-Benseler, Wörterbuch der Griechischen Eigennamen (Braun-

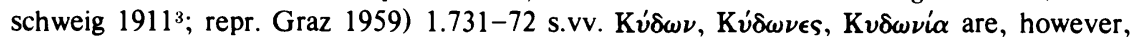
from historians, geographers, and the like. Cydonians appear twice in Homer (Od. 3.292, 19.176), but not again in poetry until the third century. 


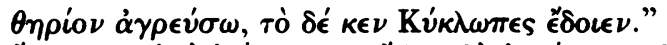

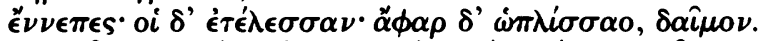

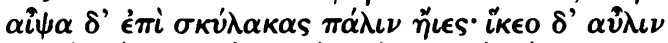

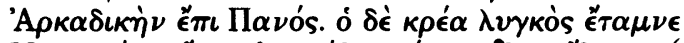

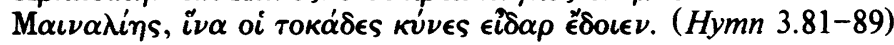

Although the context of these lines, in which Artemis addresses the Cyclopes, is at first glance unlike Gallus' situation in Ecl. 10, there are striking similarities of detail between the two passages. The most explicit connection, of course, is that both speakers specify Cydonian hunting

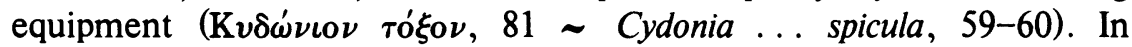
Callimachus the epithet is not merely decorative nor carelessly chosen, ${ }^{16}$ for Cydonia has a special relevance to Artemis as an important cult center. ${ }^{17}$ The significance of such a detail for the Gallus of Ecl. 10 should be apparent, since Vergil's intention is to portray him, like Milanion, as a devotee of this goddess. ${ }^{18}$ Furthermore, in both cases the Cydonian equipment is to be used in an Arcadian milieu. Both passages, in fact, mention Maenalus, the Arcadian mountain range ( $\lambda v \gamma \kappa o ́ s . .$.

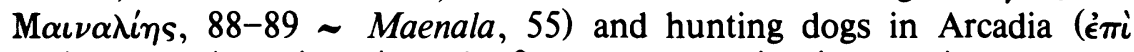

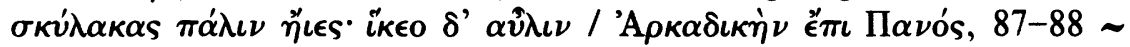
Parthenios canibus circumdare saltus, 57). Although combinations of exotic epithets are common in Hellenistic poetry, one should hesitate to explain the choice of specific epithets as random. ${ }^{19}$ By injecting Cydo-

16 Pace F. Bornmann, Callimachi Hymnus in Dianam (Firenze 1968) 42 ad loc. On "conventional" or "decorative" vs. "significant" geography in Hellenistic poetry, see N. Krevans, "Geography and the Literary Tradition in Theocritus 7," TAPA 113 (1983) 201-20.

${ }_{17}$ Strabo (10.4.12) identifies Mt. Tityros in Cydonia as the site of a Diktynnaion, i.e. a temple of Diktynna/Britomartis. While Bornmann (91), commenting on Hymn 3.190, insists that Callimachus deliberately avoids the common tendency to identify this ancient Minoan deity with Artemis, Britomartis is well attested as a Cretan $\dot{\epsilon} \pi \dot{i} \lambda \lambda \eta \sigma \iota s$ of Artemis (see Schol. on Hymn 3.190 with Pfeiffer's testimonia), and Callimachus was undoubtedly aware of the close cultic connection between the two.

${ }_{18}$ Primarily, of course, this devotion concerns Artemis/Diana as goddess of the hunt. In the elegists, Milanion takes up hunting for a purpose, i.e. in order to win over the huntress Atalanta (e.g. Propertius 1.1.9-12; Ovid, $A A$ 2.185-96, 3.775). Ross (91) argues that Gallus too had used Milanion as an exemplum of amatory obsequium. In Vergil, however, the Gallus character seems to view his hunting trip as an alternative to erotic furor. Thus the virginal aspect of Artemis/Diana seems particularly relevant to the Vergilian passage (see further below, note 34), and may have been present in Gallus' Amores as well. Aristophanes (Lys. 781-96) seems to offer an alternative tradition that represents Milanion both as a hunter in his own right, and also as a thoroughgoing misogynist.

19. The emphasis upon Arcadian and Cretan elements throughout this hymn perhaps reflects Callimachus' research into the goddess's cult. Cretan and Arcadian places, figures, and cult titles appear frequently throughout the hymn. On the whole, however, Callimachus seems to keep Cretan and Arcadian elements separate from one another. Thus we

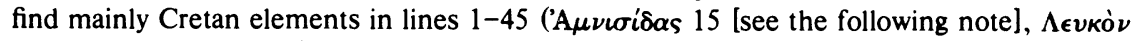

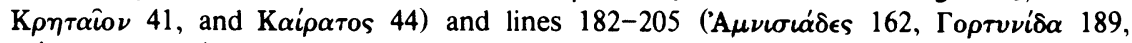

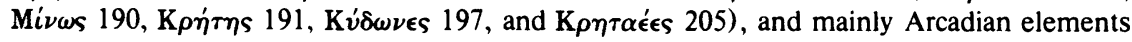


nia (59) into the unmistakably Arcadian context of Ecl. 10.55-61, Vergil reproduces the same amalgam found in the Callimachean hymn. ${ }^{20}$ Therefore, by recalling a detail that is characteristic of the Callimachean Artemis in particular, namely that she hunts even on Arcadian Mt. Maenalus with Cydonian gear, Vergil's portrayal of Gallus is able to operate on two different levels. First, Gallus as a character in the eclogue becomes a devotee of the goddess; second, since Vergil associates Gallus with Artemis in specifically Callimachean terms, he seems to imply that Gallus the poet is to be seen also as a follower of Callimachean poetics.

It is of course possible that Vergil is alluding to Callimachus directly. On the other hand, Ross posits the existence of a Milanion exemplum in the Amores by comparing Vergil's mise-en-scène (lustrabo ... Maenala, Parthenios . . . circumdare saltus) with that of Propertius 1.1.9-16, where we find Milanion hunting, like Vergil's Gallus, on Mt. Parthenius in Arcadia:21

Milanion nullos fugiendo, Tulle, labores
saevitiam durae contudit lasidos.
nam modo Partheniis amens errabat in antris,
ibat et hirsutas ille videre feras;
ille etiam Hylaei percussus vulnere rami
saucius Arcadiis rupibus ingemuit.
ergo velocem potuit domuisse puellam:
tantum in amore preces et bene facta valent.

Both Vergil and Propertius refer specifically to Mt. Parthenius-and presumably, for reasons which Ross makes clear, Gallus had done so as well. ${ }^{22}$ Similarly, Propertius alludes in this programmatic elegy (as also

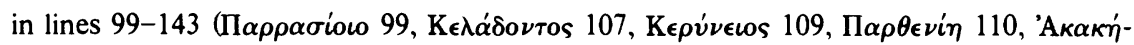

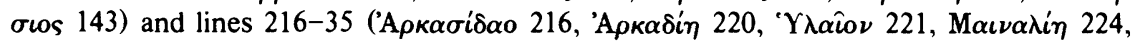

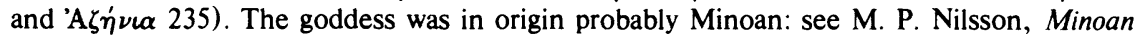
and Mycenean Religion and its Survival in the Greek Religion (Lund 1950²) 503, 518-19, 552. Crete and Arcadia are a significant pair again in Callimachus' poetry at Hymn 1 (In lovem) 4-7, where the poet debates with himself the god's actual birthplace.

${ }^{20}$ Similarly, Vergil's Gallus states that he will roam Maenalus "accompanied by the nymphs" (mixtis nymphis, 55), while in a different passage of Callimachus' hymn, Artemis petitions Zeus for twenty nymphs to accompany her on the hunt:

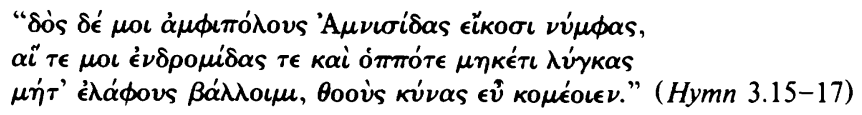

It is significant that the goddess requests nymphs of the river Amnisos in particular, since this river is in Crete. (Bornmann 13 ad loc. points out that the same nymphs attend Artemis at Apollonius, Arg. 3.881-82, and compares Aetia 3, fr. 75.25 as well.) Artemis' request for Cretan companions, therefore, parallels her request for a Cretan bow later in the hymn.

21 Ross 60-64.

22 Ross 63-64, note 5; 92, note 2 . Ross elaborates a suggestion by J. Hubaux, Les Thèmes bucoliques dans la poésie latine (Bruxelles 1930) 96, note 1, that Gallus was the first 
in the initial poem of his second book) to the love-as-disease topos by mentioning the concomitant idea of remedy:

et vos, qui sero lapsum revocatis, amici, quaerite non sani pectoris auxilia.

fortiter et ferrum saevos patiemur et ignis, sit modo libertas quae velit ira loqui. (1.26-29; cf. 2.57-70)

In this case too, comparison with $E c l$. 10 reveals a parallel idea (medicina furoris, 59) which suggests that both Propertius and Vergil are alluding to Gallus. Ross argues further that Ovid's allusive treatment of the Milanion story at $A A$ 2.185-96 indicates that Gallus was the immediate source for all three poets: ${ }^{23}$
quid fuit asperius Nonacrina Atalanta? subcubuit meritis trux tamen illa viri.
saepe suos casus nec mitia facta puellae flesse sub arboribus Milaniona ferunt;
saepe tulit iusso fallacia retia collo, saepe fera torvos cuspide fixit apros.
sensit et Hylaei contentum saucius arcum; sed tamen hoc arcu notior alter erat.
non te Maenalias armatum scandere silvas nec iubeo collo retia ferre tuo,
pectora nec missis iubeo praebere sagittis; artis erunt cautae mollia iussa meae.

The argument, briefly, is as follows. Both Propertius and Ovid name Milanion and refer to the wound that he suffered at the hands of the centaur Hylas, so there can be no doubt about what story they have in mind. ${ }^{24}$ Both openly use the story as an exemplum of amatory servitium. Both also show similarities with Gallus' words at Ecl. 10.54-60; but each of the passages contains a different set of parallel motifs. Propertius and Vergil both refer to Mt. Parthenius and to the idea of obsequium amoris. Ovid and Vergil both speak of hunting boars and of Mt. Maenalus as well. Now if Ovid were imitating Propertius, the elements that he shares with the Vergilian passage would require explanation; and unless Ovid under-

\footnotetext{
Latin poet to mention Mt. Parthenius, and that he did so as a compliment to his friend and literary mentor Parthenius of Nicaea.

${ }^{23}$ Ross 90-91.

24 While Propertius states that Milanion was wounded by Hylas' (or Hylaeus') club (Hylaei percussus vulnere rami, 1.1.13), in Ovid the centaur shoots Milanion with his bow and arrow (sensit et Hylaei contentum saucius arcum, AA 2.191). While this discrepancy might be taken as an indication that the two elegists were following different sources, most scholars believe that Ovid deliberately altered his original (namely, according to most, Propertius; according to Ross, Gallus) for the sake of creating an antithesis between Hylas' bow, an obstacle to Milanion's amatory goals, and Cupid's, the source of his passion: see M. Rothstein, Die Elegien des Sextus Propertius (Berlin 1898) 7 ad 1.1.9; F. W. Lenz, Ovid: die Liebeskunst (Berlin 1969) 201 ad 2.191ff.
} 
stood Vergil's words as an allusion to the Milanion story, it is a puzzle what would lead him to connect $E c l$. 10 with Propertius 1.1 . The simplest explanation of these parallels, as Ross persuasively argues, is that all three passages derive from a common source, namely, Gallus himself.

In light of this argument, what of the relationship that we have suggested between Ecl. 10 and Callimachus In Dianam? The same arguments that Ross uses to establish the existence of a Milanion exemplum in Gallus, as outlined above, can be used equally well to identify Callimachus' third hymn as the ultimate source of Vergil, Propertius, and Ovid. ${ }^{25}$ Vergil's and Ovid's references to Mt. Maenalus correspond

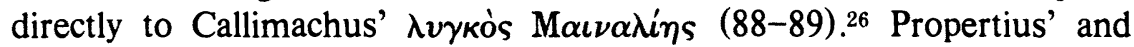
Ovid's references to the centaur Hylas (or Hylaeus) find their parallel in line 221 of the hymn. ${ }^{27}$ Finally, just as Vergil alone preserves the Callimachean epithet Cydonius, Propertius alone includes what may be a further Callimachean detail. At In Dianam 215 the poet speaks of

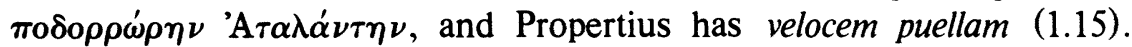
While there is nothing inherently remarkable about calling Atalanta "swift," the epithet seems more applicable to the Boeotian Atalanta, who defeated her would-be suitors in a footrace, than to the Arcadian huntress. It is the latter who is most frequently associated with Milanion, while the former in most versions of the story finally loses,

25 At this point a second passage of the hymn needs to be mentioned. In an excursus on Atalanta (lines 215-24), which is reminiscent of the earlier passage of the hymn describing Artemis' own activities (81-89), Callimachus demonstrates how natural it is to associate Artemis with Atalanta (and by implication with the Milanion/Atalanta myth) when he explicitly mentions how the goddess instructed her disciple in the art of hunting. In both passages we find references to hunting $(85 \sim 217)$, dogs $(87 \sim 217)$, archery $(87 \sim 217$, 222-23), and Maenalus (89 224), all of which, as we noted above, also appear in the Vergilian exemplum. Callimachus, moreover, in his description of Atalanta emphasizes her

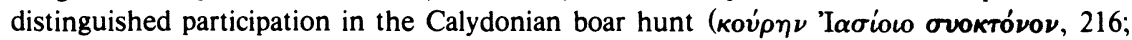

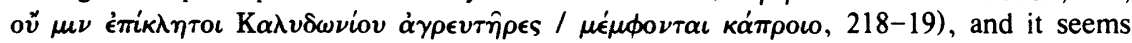
possible that this detail lies behind the wild boars of Vergil's passage (56), since Milanion was also a member of that expedition. He and Atalanta are portrayed conspicuously as a hunting pair on the François vase (see J. Boardman, Athenian Black Figure Vases [Oxford 1974] plate 46.3 and G. Daltrop, Die Kalydonische Jagd in der Antike [Hamburg 1966] 15-16) where they are standing side by side on the vase facing the boar and gesticulating in precisely the same manner.

The affinity between Artemis and Atalanta is more than casual. It is usually held that Atalanta was in fact an Arcadian form of Artemis, who was gradually transformed into a follower of the goddess (cf. K. Hohn, Artemis [Zurich 1946] 18-19 and W. H. Roscher, Ausführliches Lexicon der griechischen und römischen Mythologie [Leipzig 1884-1937] 1.1.667 s.v. "Atalante"). It is clear that the events Callimachus mentions in the hymn-the Calydonian boar hunt, the spurning of the sexual advances of Hylaeus and Rhoecus-depict Atalanta as emulating Artemis, and thus establish a strong link between them.

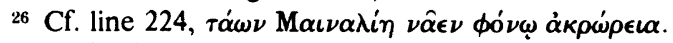

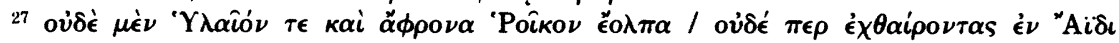

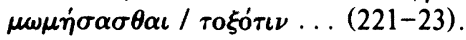


because of the golden apples stratagem, to Hippomenes. ${ }^{28}$ While it is only too typical of the doctus poeta to conflate legends in this way, ${ }^{29}$ it seems likely that Propertius' velocem in this context, when viewed alongside the other parallels mentioned above, points to Callimachus as the ultimate source of the material found in all these Milanion passages.

It should also be clear that if Callimachus' hymn is accepted as the ultimate source of Vergil's lines, then Ross's argument for a Gallan Milanion passage is strengthened. While it remains possible, as noted above, that Vergil himself borrowed elements directly from In Dianam in order to portray his Gallus as a devotee of that goddess, it would be remarkable if Propertius and Ovid at a later date independently drew on both the Vergilian and Callimachean passages in contexts that concerned Milanion. It is at any rate more economical, and much more plausible as well, to suppose that it was Gallus who drew on Callimachus directly, borrowing details from the Artemis hymn to lend a suitable color to the story of Milanion's Arcadian excursion. ${ }^{30}$ Once Callimachus' Artemis had been transformed, so to speak, into Gallus' Milanion, Gallus' followers were then free to draw upon his reworking of Callimachus as it suited their several purposes.

The reference to Gallus' Milanion exemplum that Ross detects in lines 55-61 immediately follows the aforementioned allusion to Gallus' Acontius (52-54). At first reading, Vergil's handling of his putative Gallan allusions appears somewhat careless. In the same breath, it seems, he

28 The Arcadian version often gives Meleager as well as or instead of Milanion as Atalanta's suitor, and involves the episode of the Calydonian boar-hunt. The Boeotian version regularly features Hippomenes: ps.-Apollodorus (3.9.2) ascribes this version to Euripides (possibly in the Meleager: see frr. 515-39 Nauck), but himself gives a version in which Milanion, not Hippomenes, prevails in a footrace. For references to both lovers (and to the additional dispute about Atalanta's parentage) see Roscher 1.1.664-66; RE 2.2 (1896) 1890-93; J. G. Frazer's note on Apollodorus 3.9 .2 in the Loeb edition (London 1921), vol. 1, pp. 398-99; F. Bömer, P. Ovidius Naso: Metamorphosen X-XI (Heidelberg 1980) 188-90.

29 Such deliberate contaminations of variant narrative traditions are held by some to be a neoteric trademark: see, e.g., E. Norden on Aen. 6.14; Ross 38 and 62; Coleman (above, note 13 ) on $E c l$. $6.74 \mathrm{ff}$. By the same token, Ovid seems to have felt free to draw upon both versions as it suited him in different contexts. In $A A$ 2.187-90, he follows the Arcadian version by having Milanion help Atalanta in the hunt; but in Met. 8.260-546 (the Calydonian boar hunt) Meleager is Atalanta's lover, while elsewhere (Met. 10.560-707) Ovid tells the normal Boeotian story of Hippomenes and the footrace.

${ }^{30}$ It is not difficult to see how Gallus, with the hymn to Artemis in mind, could draw on attributes common to both the goddess and her follower Atalanta in relating the adventures of Milanion in Arcadia. Milanion's mythological fame, after all, rests largely on his love for Atalanta, and it would be fitting for him to be portrayed in terms of his relationship with her. By the same token, Vergil's allusion to Gallus' Milanion exemplum preserves elements that Gallus had borrowed from each of the Callimachean figures, namely Artemis and Atalanta, on whom his Milanion was based. 
makes his Gallus cast himself first as Acontius, then as Milanion, without developing any connection between the two or even making an explicit transition from one to the other. ${ }^{31}$ But there are several factors that facilitate the juxtaposition of the two figures. Both, of course, are desperately in love with girls, Cydippe and Atalanta, who are known for their resolute chastity and their devotion to Artemis. ${ }^{32}$ Both take to the wilds in a fit of

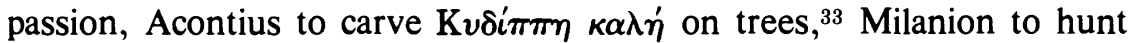
like Atalanta. There is also the matter of Acontius' name, which means

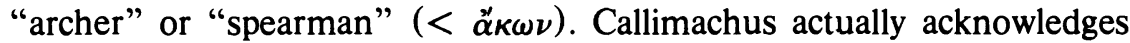
this etymology by calling Acontius a $\tau 0 \xi \epsilon v \tau \eta \dot{s}$ (fr. 70.2 Pf.). ${ }^{34}$ This fact allows Vergil more plausibly to locate his Gallus/Acontius inter spelaea ferarum (52) and, what is more to the point, makes possible a further connection between Acontius and Milanion the hunter. Most important, both figures had perhaps been implicitly united in the Amores by their paradigmatic relevance to Gallus in his elegiac persona. ${ }^{35}$ Still, one may ask, what in Vergil's language supports the notion that lines 52-54 allude specifically to Gallus' imitation of Callimachus' Acontius?

Two elements in particular-the words Cydonia and spicula-present themselves. Although both words occur in the Milanion passage, their relevance to Acontius will presently be made clear. It seems likely that Vergil chose the words that describe Milanion's equipment, along with all the other epithets that he uses here, for their symbolic as well as their literary-historical associations. Gallus' projected hunting trip represents his intention to come to terms with his erotic passion through personal devotion to the chaste Diana; ${ }^{36}$ and Vergil's diction, according to G. Doig, symbolizes this intention. ${ }^{37}$ The progression of Arcadian epithets from Maenala to Parthenios stands for Gallus' passage from a life of amatory furor ( $\mu \alpha \nu i \alpha, \mu \alpha i \nu o \mu \alpha \iota \sim$ Mai $\nu \alpha \lambda \alpha$ ) to one of renunciation $\left(\pi \alpha \rho \theta \epsilon \nu i \alpha \sim\right.$ Parthenios) ${ }^{38}$ In light of these associations, both

31 Such abrupt transitions between different stories are also prominent in Ecl. 6, in which Gallus also appears. Was this sort of allusiveness for Vergil's audience an identifiably Gallan mannerism?

:32 Cydippe's devotion to Artemis is evident in all aspects of the story, from her virginity, to the oath taken in Artemis' temple by which she traps herself into marrying Acontius (see Aristaenetus 1.10, quoted below, p. 252), to the wording of Apollo's announcement to her father that she must marry Acontius (fr. $75.22 \mathrm{Pf}$.).

33 Fr. 73.2 Pf.

34 Callimachus is probably using $\tau 0 \xi \epsilon v \tau \dot{\eta} s$ metaphorically here: the one who had smitten so many others with the shafts of his beauty is now ironically stricken in turn by the beauty of Cydippe. So Pfeiffer 75 ad loc., adducing Aristaenetus 1.10 and frr. 68 and 69.

35 Ross 91.

36 Above, note 18.

37 "Vergil's Art and the Greek Language," CJ 64 (1968/69) 5-6.

38 Doig (above, note 37) 5-6. Maenalus, as Doig (4) observes, is frequently associated with Pan (cf. Theocritus, Id. 1.123-24; Vergil, Geo. 1.17), himself a god of madness ( $\tau \dot{\text { o }}$ 
Partho and Cydonia gain force. Partho, as Doig suggests, by echoing Parthenios may be intended to emphasize that word. ${ }^{39}$ The effect of this emphasis will perhaps be to stress the idea of chastity, and so to indicate the ultimate source of these lines, Callimachus' hymn to the virgin goddess. Cydonia, on the other hand, is the epithet not only of the best hunting equipment, but also of quinces-in Latin, Cydonia mala. ${ }^{40}$ Indeed, Cydonia itself is frequently used substantivally-i.e. without mala-to mean "quinces." 41 Therefore, even though Vergil does not explicitly speak of Cydonia mala, the epithet alone is sufficient to bring quinces to mind. One may object that this would not be the case in a passage where Cydonia explicitly modifies an entirely different word, such as spicula; but there is a close connection between Cydonia spicula and Cydonia mala even apart from their shared epithet. The relationship is in fact antithetical, because quinces are amply attested as a remedy for $\tau$ ò $\tau \circ \xi \iota \kappa o ́ \nu$, or arrow-poison. ${ }^{42}$ The relevance of quinces to the Vergilian passage is therefore brought out by the poetically unusual phrase medicina furoris (59). ${ }^{43}$ This interpretation, first advanced by Doig, ${ }^{44}$ has recently been corroborated by B. W. Boyd, ${ }^{45}$ who refers to a similarly worded passage in Aeneid 12:

non secus ac nervo per nubem impulsa sagitta, armatam saevi Parthus quam felle veneni, Parthus vel Cydon, telum immedicabile, torsit, stridens et celeris incognita transilit umbras: talis se sata Nocte tulit terrasque petivit. $(856-60)$

Here Vergil (for whatever reason) uses the same combination of epithets as in $E c l$. 10.59 , again in close proximity with a word that refers to medicine or healing. It therefore seems likely, as Boyd argues, that the words Cydon and Cydonia in both passages refer to Cydonia's fame as a source both of excellent hunting equipment and of medicine for wounds inflicted by such weapons. In the amatory context of $E c l$. 10 , both ideas also refer to Gallus' futile hope that hunting with Cydonian gear will

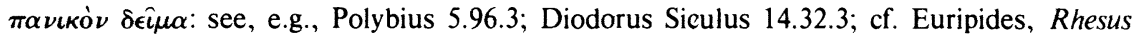
36-37; Wilamowitz, Der Glaube der Hellenen [Berlin 1931] 1.248, note 2).

39 Above, note 37 .

${ }^{40}$ Cf. Pliny, NH 15.11.37; Columella 12.2.4; Petronius 69.7. OLD (s.v. cotoneus) explains the equivalent term cotoneum (malum) as "prob. cogn. w. but not derived from Gk. $(\mu \hat{\eta} \lambda \alpha) \mathrm{K} v \delta \dot{\omega} \nu\llcorner\alpha " ;$ cf. Macrobius, Sat. 7.6.13.

${ }^{41}$ Propertius 3.13.27; Ovid, $A A$ 3.705; Columella 12.47.1; Martial 10.42.3.

42 Theophrastus, HP 2.2.5; Nicander, Alex. 234-35; etc.

${ }_{43}$ H. Tränkle, Die Sprachkunst des Properz und die Tradition der lateinischen Dichtersprache, Hermes Einzelschriften 15 (Wiesbaden 1960) 22-23; cf. Ross 67-68. Quinces, like other types of mala, also appear frequently in poetry as a love-offering, as in Propertius 3.13.27 (above, note 41).

44 Above, note 37.

45 “Cydonea mala: Virgilian Word-Play and Allusion," HSCP 87 (1984) 169-74. 
prove to be a medicina furoris, a remedy for his lovesickness. ${ }^{46}$ Here we may return to Acontius and to the means by which he overcame Cydippe's resistance. Although the relevant portion of the Aetia is lost, the most important element can be supplied from Aristaenetus' paraphrase:

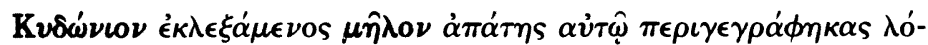

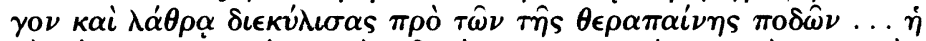

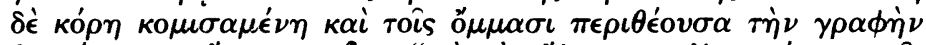

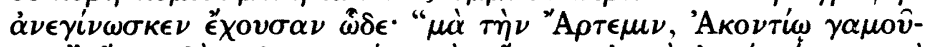

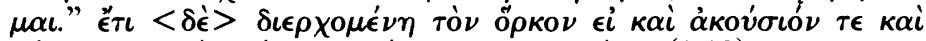

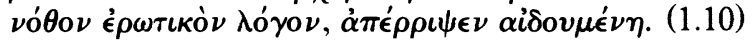

The paraphrase unambiguously preserves a common verbal elementthe adjective $K \boldsymbol{v} \delta \dot{\omega} \boldsymbol{\nu} \nu$ เos-between the two Callimachean poems under discussion: it is clear that the epithet must have been present in Aetia 3 as well as at In Dianam $81 . .^{47}$ In modeling his Acontius and his Milanion on these passages, Gallus will undoubtedly have incorporated a sufficient amount of verbal detail to indicate his source. Thus his Acontius will have tricked Cydippe with a Cydonian apple (or quince), and his Milanion will have hunted with a Cydonian bow. Vergil in turn recognized this similarity and incorporated it into his imitation, leaving it for the alert reader to draw the connection between the Gallan exempla for himself. ${ }^{48}$ At this point, however, one may ask two questions. What in the phrase Cydonia spicula, a phrase that occurs, after all, only in connection with Milanion, would cause a reader to suspect an allusion to Acontius; and why does Vergil speak of Cydonian arrows where Callimachus (and presumably Gallus) had a Cydonian bow? The second question, we believe, answers the first. Vergil's alteration of Callimachus' $\tau$ ó $\xi o \nu$ (and, let us say, of Gallus' cornu ${ }^{49}$ or arcus $^{50}$ ) to spicula

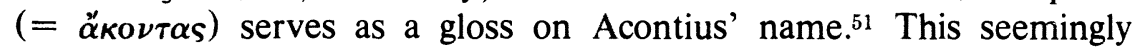
gratuitous alteration, we believe, is an example of Vergil's wish to develop a further verbal connection between the two figures to whom his Gallus is implicitly compared. Thus the phrase Cydonia spicula in

\footnotetext{
46 Boyd (above, note 45) 173.

${ }_{47}$ Pfeiffer (vol. 1, p. 76) places the quince-episode just before fr. 72 in his collection.

48 There is no reason to believe that the two stories were explicitly connected in the Amores. Propertius' allusions to them are widely separated (appearing in poems 1.1 and 1.18 ), and do not seem to be mutually connected in any way. The juxtaposition of references to these exempla and the verbal relationships developed between them in Ecl. 10 thus appear to be Vergil's own idea.

49. If Gallus used this word, then Vergil's clausula Cydonia cornu (Ecl. 10.59) will have served both to recall his source(s) and to call attention to his own variation.

50 Cf. Horace, Carm. 4.9.17-18, Cydonio arcu.

${ }_{51}$ Cf. Propertius' gloss in his Milanion passage (durae $[\sim \dot{\alpha}-\tau \lambda \alpha-\sim$ 'A $\tau \alpha \lambda \dot{\alpha} \nu \tau \eta \eta$ lasidos, 1.1.10), where the name Atalanta itself does not appear. Vergil's and Propertius' bilingual punning may well reflect a feature of their Gallan original: see Ross 62, n. 2.
} 
Ecl. 10 refers (by way of Gallus' Amores) both to the weapons of Artemis in Callimachus' hymn-appropriate gear for Gallus in the guise of Milanion-and to Acontius' means of conquest in Callimachus' Aetia.

As a further illustration of this connection between the two stories we adduce the following passages. The poet of Heroides 2152 (Cydippe to Acontius) spells out the same two points by which Vergil in Ecl. 10, with greater subtlety, unites his paired allusions to Gallus' exempla. The first of these is the quince/apple motif. In reproving her lover for the stratagem whereby he overcame her resistance, the deceived heroine compares her situation to that of Atalanta, asking:

Cydippen pomum, pomum Schoeneida cepit; tu nunc Hippomenes scilicet alter eris? (125-26)

Later in the same poem, the etymology of Acontius' name is brought out by means of a pun:

mirabar quare tibi nomen Acontius esset; quod faciat longe vulnus, acumen habes. (211-12)

The fact that these very elements appear in Heroides 21 supports our contention that Vergil could have seen the Gallan exempla alluded to in $E c l .10$ as being closely associated, not merely sequential. In light of the Heroides parallels, it seems likely that Vergil, as we have argued, expressed this association by drawing attention to Acontius' name, which connects him etymologically with Milanion's role as a hunter, and to the Cydonian products by means of which the two lovers achieved their amatory goals..$^{53}$

${ }^{52}$ The authorship of several of the Heroides epistles has often been questioned. The most recent defender is E. J. Kenney, "Two Disputed Passages in the Heroides," CQ 29 (1979) 394-431; contra, see R. J. Tarrant, "The Authenticity of the Letter of Sappho to Phaon (Heroides 15)," HSCP 85 (1981) 133-53.

${ }_{53}$ Vergil's treatment of these exempla is so understated that he can hardly be suggested as the Heroides-poet's source. Neither pair of lovers, after all, is actually named in Ecl. 10. Such an extreme of allusiveness suggests the existence of a more overt treatment elsewhere; and in light of the other motifs that are common to Propertius 1.1, Ecl. 10, and the Ars amatoria (above, note 3), Gallus becomes the obvious choice. Here too, though, we find little evidence of direct Gallan influence on the Heroides-poet: Propertius 1.1 virtually guarantees that Gallus spoke of Milanion (9), and of Atalanta as the daughter of Iasus (10) - not, as does the Heroides-poet, of Hippomenes (212), and of Atalanta as the daughter of Schoeneus (211). Similarly, assuming that Gallus' treatment of Acontius followed that of Callimachus, we may conjecture that he used the cognate expression (Cydonia) mala rather than poma (Her. 21.211). It remains possible, of course, that the Heroidespoet deliberately altered his source. On the other hand, he may well have developed the pun between Acontius and acumen independently of Vergil's alteration of Callimachus'

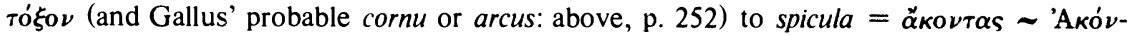
$\tau \omega s$; and on the whole it seems reasonable to allow the anonymous poet a modicum of independence. 


\section{Postscript}

Ross's postulation of a Milanion exemplum in Gallus' Amores seems to have attracted more attention than that of an equally important Acontius exemplum. The reason may be that Ross puts the case for a Gallan Milanion in somewhat stronger terms than he uses to argue for Acontius. ${ }^{54} \mathrm{We}$, however, believe that an additional piece of evidence can be adduced in favor of a Gallan Acontius passage. In the catalogue of nymphs in Geo. 4.336-45 we find these lines:

Cydippe et flava Lycorias, altera virgo, altera tum primos Lucinae experta labores. (339-40)

This obvious pairing of Cydippe and Lycorias, we suggest, was inspired by a perhaps implicit comparison between Cydippe and Lycoris, complementary to a comparison between Acontius and Gallus, in the Amores. Although many Cydippes appear in Greek literature (none of them nymphs, however), in Latin the name always denotes Callimachus' heroine, except here. Similarly, Lycorias is a virtual unicum..$^{55}$ The name is unknown in Greek. Vergil can hardly have chosen such names at random, nor is their combination fortuitous. ${ }^{56}$

54 "Finally, we can, I think, be almost certain about this passage of Gallus: somewhere in his elegies he related the Callimachean story of Acontius and Cydippe (as we can tell from Propertius 1.18) ..." (Ross 91); "But what amounts to absolute proof that these lines of the Tenth Eclogue and Propertius' exemplum not only are intimately related but both derive from the same passage (which can only have been Gallus) is afforded by Ovid, who uses the same Milanion-Atalanta story as an exemplum of obsequium ... precisely as does Propertius" (Ross 90). The character of the evidence for both passages, of course, is essentially the same.

${ }^{55}$ Hyginus' list of fifty Nereids (Fab., praef. 28-29 Bunte), which contains the only other occurrence of Lycorias in Latin, is an obvious combination of Homer's catalogue (Il. 18.39-48) for the first thirty-four names (Glauce to Amatheia) with Vergil's (Geo. 4.336-45) for the latter fourteen (Drymo to Arethusa-this despite the fact that Vergil calls two of these nymphs, Clio and Beroe, Oceanitides [341]).

56 The fact that Vergil's Cydippe is still a virgin while Lycorias has just given birth may be an ironic comment on the discrepancy between Cydippe's committed chastity and Lycoris' licentious conduct. Indeed, the collocation of Cydippe and Diana Lucina itself may be an allusion to Callimachus: Artemis Eileithyia is found among the subjects of Aetia 3 (the same book as Acontius and Cydippe), fr. 79 Pf.; cf. Servius on Ecl. 4.10 and on Aen. 3.73. With this in mind, it may be relevant that Vergil's catalogue occurs at the point where Aristaeus descends to the bottom of the river Peneus to visit his mother Cyrene. Aristaeus, according to Callimachus, was the $\gamma \alpha \mu \beta \rho$ ós of Acontius (Aetia 3, fr. 75.33-35 Pf.); Cyrene, of course, was the birthplace of Callimachus.

Another sign that these lines may have a Gallan background is the evident neotericism of the first line (two Greek names; hiatus after Cydippe; observance of bucolic diaeresis) along with the technical duritia of the second (spondees in the second, third, and fourth feet; elided diphthong in Lucinae), apparently a typically Gallan juxtaposition. For this and many other helpful suggestions we are indebted to the anonymous referee. 